\title{
Crop Response to Soil Acidity Factors in Ultisols and Oxisols in Puerto Rico. XIII. Cabbage ${ }^{1,2}$
}

\author{
Edmundo Rivera, José Rodriguez and Fernando Abruña ${ }^{3}$
}

\begin{abstract}
The effect of acidity factors of two Ultisols and one Oxisol on yield and foliar composition of cabbage was determined. On all soils, cabbage responded markedly in yield to liming, but response was stronger on the ultisols. All soil acidity factors correlated significantly with yields. On the Ultisols, yields increased with decreasing acidity up to the highest level of limiting, pH 5.6. Only $50 \%$ of maximum yield was obtained at $12-13 \%$. Al saturation of the CEC and essentially no yields were produced at pH values below 4.5 with $50 \%$ Al saturation, a level of acidity common in Ultisols. About $50 \%$ of maximum yield was obtained at $\mathrm{pH} 4.7$ with $25 \%$ Al saturation on the Oxisols compared with about $22 \%$ of maximum yield obtained at this level of acidity on the Ultisols. Density of the cabbage heads correlated positively with soil acidity on all soils. Soil acidity had no apparent effect on foliar composition of the basal leaves. Calcium content of the head leaves correlated negatively with soil acidity factors on the Ultisols. Basal leaves had a higher $\mathrm{Ca}$ content than head leaves and both had a higher $\mathrm{Ca}$ and a lower $\mathrm{P}$ content on the Coto soil than on the Corozal soils.
\end{abstract}

\section{INTRODUCTION}

About 3,800 tons of cabbage are produced yearly in Puerto Rico and about 5,500 tons are imported from the United States and Dominican Republic (3). Local production, formerly concentrated in the east-central mountain area near Orocovis and Barranquitas (11), now comes mostly from irrigated plantings on the semi-arid south coast.

Little information is available on the effects of liming and soil acidity factors on head cabbage. Green (5) in Hawaii found no response by cabbage to lime applications on a Kula loam (Ultisol) with $\mathrm{pH}$ 5.5, a level at which active $\mathrm{Al}$ is not present in appreciable amounts, but soluble $\mathrm{Mn}$ may occur if the Mn pool of the soil is high. Maynard et al. (9) studied the relation between liming and internal tipburn of cabbage and found that $\mathrm{Ca}$ accumulated in the basal leaves rather than in the head leaves.

The present study determined the relationship between the various soil acidity factors and yield and chemical composition of cabbage in field experiments on two Ultisols and one Oxisol.

\footnotetext{
${ }^{1}$ Manuscript submitted to Editorial Board July 5, 1984.

${ }^{2}$ This paper covers work carried out cooperatively between the Agricultural Research Service, USDA and the Agricultural Experiment Station, College of Agricultural Sciences, Mayagüez Campus, University of Puerto Rico.

${ }^{3}$ Agronomist, ARS-USDA; Associate Agronomist, Agricultural Experiment Station, College of Agricultural Sciences, Mayaüez Campus, University of Puerto Rico, and Soil Scientist, ARS, USDA, respectively.
} 


\section{MATERIALS AND METHODS}

The experiments were carried out in plots with widely varying levels of soil acidity resulting from differential applications of limestone over a period of years.

The experiments were carried out on Corozal clay (Aquic Tropudults) and Corozal clay subsoil (desurfaced Corozal clay soil) near Corozal and on Coto sandy clay (Tropeptic Haplorthox) near Isabela. There were 30 $4 \times 4 \mathrm{~m}$ plots on each of the Ultisols and 42 on the Oxisol. The plots were surrounded by $15 \mathrm{~cm}$-deep ditches to prevent runoff from one plot into another.

Seedlings of the Market Prize hybrid were planted in all plots in September 1978 at $30 \times 45 \mathrm{~cm}$. Overhead irrigation was applied whenever rainfall was less than $25 \mathrm{~mm}$ weekly. Plots were irrigated four times at Isabela and once at Corozal. All plots received one T/ha of 10-10-10 fertilizer containing $30 \mathrm{~kg} / \mathrm{T}$ of a minor element mixture with $6 \% \mathrm{Mg}$, $4.8 \% \mathrm{Cu}, 7 \% \mathrm{Fe}, 8 \% \mathrm{Zn}$ and $2.4 \% \mathrm{~B}$, divided into 2 equal applications at planting and 30 days later. Weeds were controlled by periodic hoeing and insects and diseases with pesticides according to recommendations of the U.P.R. Agricultural Experiment Station.

Basal and head leaves from plants in the center row of each plot were sampled 60 days after planting and analyzed for $\mathrm{Ca}$ and $\mathrm{Mg}$ by the Versenate method; K by flame photometry; Mn colorimetrically after oxidation with $\mathrm{KIO}_{4} ; \mathrm{P}$ colorimetrically as molybdate and $\mathrm{N}$ by Kjeldahl method.

The soil in each plot was sampled at the beginning of the experiment by taking 10 borings at $0-15 \mathrm{~cm}$ depth. The samples were air dried and screened through a 10 -mesh sieve. Exchangeable bases $(\mathrm{Ca}+\mathrm{Mg}+\mathrm{K})$ were extracted with $\mathrm{N} \mathrm{NH} \mathrm{NHAC}_{4} \mathrm{Ot} \mathrm{pH}$ 7.0. Calcium and $\mathrm{Mg}$ were determined by the Versenate titration method (4) and $\mathrm{K}$ by flame photometry. Exchangeable $\mathrm{Al}$ was extracted with $N \mathrm{KCl}$ and determined by the double titration method (10). Percent Al saturation of the effective cation exchange capacity (CEC) was determined by dividing the exchangeable $\mathrm{Al}$ content by the sum of the exchangeable cations, $\mathrm{Ca}, \mathrm{Mg}$, $\mathrm{K}, \mathrm{Al}$ and $\mathrm{H}$. Soil reaction was measured by a glass electrode with 1:1.5 soil to water ratio.

Yields were recorded for each plot. Only heads weighing $0.5 \mathrm{~kg}$ or more were considered of commercial value. Six heads from each plot were used to determine firmness according to the waterdisplacement method described by Pearson (12).

For statistical analysis, plots were grouped in $15 \% \mathrm{Al}$ saturation ranges with 0 as a separate range. Yield data and chemical composition of the leaves were correlated with soil acidity factors through regression analysis. 


\section{RESULTS AND DISCUSSION}

Cabbage responded strongly to liming up to the highest level tested on all three soils (table 1). Highest yields were attained at the lowest level of acidity, above $\mathrm{pH} 5.6$ with no exchangeable Al.

Response to the last increment of lime was very strong on the Ultisols. On Corozal clay, yields dropped to $66 \%$ of maximum when $\mathrm{pH}$ decreased from 6.0 to 5.1 and $\mathrm{Al}$ saturation increased from 0 to $12 \%$ and on the subsoil to $43 \%$ of maximum when $\mathrm{pH}$ decreased from 5.55 to 5.0 , and $\mathrm{Al}$

TABLE 1.-Effect of soil acidity factors on yields and quality of cabbage growing on two Ultisols and one Oxisol

\begin{tabular}{|c|c|c|c|c|c|c|}
\hline \multicolumn{5}{|c|}{ Soil acidity factors } & \multirow[b]{2}{*}{ Yields } & \multirow[b]{2}{*}{ Density of heads } \\
\hline $\mathrm{pH}$ & Exch. Al & $\mathrm{Al}$ sat. & Ca sat. & $\frac{\mathrm{Al}}{\mathrm{Ca}}$ & & \\
\hline & $m e / 100 \mathrm{~g}$ & $\%$ & $\%$ & & $\mathrm{~kg} / \mathrm{ha}$ & $\mathrm{g} / \mathrm{cm}^{3}$ \\
\hline \multicolumn{7}{|c|}{ Corozal clay soil (Aquic Tropudult) } \\
\hline 6.00 & 0 & 0 & 73 & .00 & 11,440 & .88 \\
\hline 5.10 & 1.31 & 12 & 60 & .21 & 6,430 & .88 \\
\hline 4.90 & 3.36 & 26 & 49 & .44 & 3,060 & .98 \\
\hline 4.70 & 4.12 & 37 & 43 & .88 & 810 & .96 \\
\hline 4.40 & 6.41 & 52 & 30 & 1.75 & 430 & .99 \\
\hline 4.25 & 8.14 & 67 & 17 & 4.35 & 0 & 1.06 \\
\hline 4.10 & 10.44 & 80 & 9 & 8.90 & 0 & - \\
\hline \multicolumn{7}{|c|}{ Corozal clay-subsoil (Aquic Tropudult) } \\
\hline 5.55 & 0 & 0 & 64 & .00 & 13,510 & .86 \\
\hline 5.00 & 1.37 & 13 & 64 & .19 & 4,280 & .92 \\
\hline 4.75 & 3.09 & 27 & 49 & .56 & 2.700 & .94 \\
\hline 4.60 & 4.29 & 40 & 37 & 1.11 & 180 & .95 \\
\hline 4.50 & 5.35 & 54 & 23 & 2.38 & 60 & .96 \\
\hline 4.20 & 7.29 & 68 & 14 & 6.06 & 0 & - \\
\hline 3.95 & 9.02 & 79 & 14 & 7.58 & 0 & - \\
\hline \multicolumn{7}{|c|}{ Coto sandy clay (Tropeptic Haplorthox) } \\
\hline 5.60 & 0 & 0 & 52 & .00 & 18,080 & .79 \\
\hline 5.05 & .28 & 6 & 51 & .12 & 14,640 & .82 \\
\hline 4.90 & .76 & 16 & 45 & .37 & 11,362 & .83 \\
\hline 4.70 & 1.20 & 25 & 39 & .68 & 9,240 & .86 \\
\hline 4.55 & 1.51 & 34 & 34 & 1.00 & 6.060 & .86 \\
\hline
\end{tabular}

saturation increased from 0 to $13 \%$. Almost no yields were obtained below about $\mathrm{pH} 4.5$ and $50 \% \mathrm{Al}$ saturation of the soil, an acidity level common in Ultisols.

Higher yields were obtained on the Oxisol; the effects of soil acidity were not as striking as on the Ultisols. About $50 \%$ of maximum yields were obtained at $\mathrm{pH} 4.7$ with $25 \% \mathrm{Al}$ saturation compared with only 27 and $20 \%$ at this level of acidity on the Corozal soil and subsoil, respectively. This lower response to lime on the Oxisol as compared to the Ultisols has been observed with various crops $(1,2)$. At comparable 
acidity levels, $\mathrm{Al}^{3+}$ molar activity in the soil solution of Oxisols in Puerto Rico is less than in Ultisols, whereas $\mathrm{Mn}^{2+}$ molar activity is higher (13). As a result, crops sensitive to $\mathrm{Al}$, but tolerant to $\mathrm{Mn}$, respond less to liming on these soils than on Ultisols. Harward et al. (6) found that toxic levels of $\mathrm{Al}$ in solution depressed the $\mathrm{Mn}$ content of mature lettuce leaves. Hiatt and Ragland (8) noted that Mn content of leaves of burley tobacco

TABLE 2.-Correlation coefficients between soil acidity factors and yield and chemical composition of cabbage grown on two Ultisols and one Oxisol

\begin{tabular}{|c|c|c|c|c|c|c|c|}
\hline \multirow{3}{*}{ Independent variable (X) } & \multirow{3}{*}{$\begin{array}{l}\text { Yields } \\
(\mathrm{Y})\end{array}$} & \multirow{3}{*}{$\begin{array}{c}\text { Head } \\
\text { density }(\mathrm{Y})\end{array}$} & \multicolumn{5}{|c|}{ Chemical composition (Y) } \\
\hline & & & \multicolumn{3}{|c|}{ Basal leaf } & \multicolumn{2}{|c|}{ Head leaves } \\
\hline & & & $\mathrm{Ca}$ & $\mathrm{Mg}$ & $\mathrm{Mn}$ & $\mathrm{Ca}$ & $\mathrm{Mg}$ \\
\hline \multicolumn{8}{|c|}{ Corozal clay soil } \\
\hline $\mathrm{pH}$ & $.87^{* *}$ & $.65^{* *}$ & N.S. & N.S. & N.S. & $.68^{* *}$ & N.S. \\
\hline$\% \mathrm{Al}$ saturation & $.86^{* *}$ & $.76^{* *}$ & N.S. & N.S. & N.S. & $.68^{* *}$ & N.S. \\
\hline $\begin{array}{l}\% \text { Ca saturation } \\
\text { Exch. Al }\end{array}$ & $.80^{* *}$ & $.84^{* *}$ & N.S. & N.S. & N.S. & $.61^{* *}$ & N.S. \\
\hline$\overline{\text { Exch. Ca }}$ & $.58^{*}$ & $.85^{* *}$ & N.S. & N.S. & N.S. & $.61^{* *}$ & N.S. \\
\hline Head density & $.61^{* *}$ & - & - & - & - & - & - \\
\hline$\% \mathrm{Ca}$ in head leaves & $.55^{*}$ & N.S. & - & - & - & - & - \\
\hline \multicolumn{8}{|c|}{ Corozal clay subsoil } \\
\hline $\mathrm{pH}$ & $.90^{* *}$ & $.87^{* *}$ & N.S. & N.S. & N.S. & $.59^{*}$ & N.S. \\
\hline$\% \mathrm{Al}$ saturation & $.79^{* *}$ & $.72^{* *}$ & N.S. & N.S. & N.S. & $.63^{* *}$ & N.S. \\
\hline $\begin{array}{l}\% \text { Ca saturation } \\
\text { Exch. Al }\end{array}$ & $.73^{* *}$ & $.72^{* *}$ & N.S. & N.S. & N.S. & $.61^{* *}$ & N.S. \\
\hline$\overline{\text { Exch. Ca }}$ & $.55^{*}$ & $.72^{* *}$ & N.S. & N.S. & N.S. & $.63^{* *}$ & N.S. \\
\hline Head density & $.85^{* *}$ & - & - & - & - & - & - \\
\hline$\% \mathrm{Ca}$ in head leaves & $.58^{*}$ & - & - & - & - & - & - \\
\hline \multicolumn{8}{|c|}{ Coto sandy clay } \\
\hline $\mathrm{pH}$ & $.67^{* *}$ & $.59^{* *}$ & N.S. & N.S. & $.60^{* *}$ & N.S. & N.S. \\
\hline$\%$ Al saturation & $.68^{* *}$ & $.51^{*}$ & N.S. & N.S. & $.56^{*}$ & N.S. & N.S. \\
\hline $\begin{array}{l}\text { \% Ca saturation } \\
\text { Exch. Al }\end{array}$ & $.54^{*}$ & $.50^{*}$ & N.S. & N.S. & $.56^{*}$ & N.S. & N.S. \\
\hline$\overline{\text { Exch. Ca }}$ & $.68^{* *}$ & $.53^{*}$ & N.S. & N.S. & $.59^{* * *}$ & N.S. & N.S. \\
\hline Head density & $.63^{* *}$ & - & - & - & - & - & - \\
\hline$\% \mathrm{Ca}$ in head leaves & N.S. & N.S. & - & - & - & 一 & - \\
\hline
\end{tabular}

decreased when $\mathrm{Al}$ was present, whereas $\mathrm{Mn}$ had little influence on $\mathrm{Al}$ content of leaves. On the other hand, Hewitt (7) reported than Mn toxicity symptoms were increased by presence of Al. Thus, the apparent effects of $\mathrm{Mn}$ and $\mathrm{Al}$ molar activity should be investigated further.

Density of the cabbage heads increased with increasing acidity on all soils (tables 1 and 2). 
Soil acidity factors had no apparent effect on composition of the basal leaves (table 2 and 3 ) although $\mathrm{N}$ content tended to increase with increasing acidity and $\mathrm{Mn}$ content on the Coto soil increased slightly with increased acidity. The basal leaves had a higher $\mathrm{Ca}, \mathrm{Mg}$ and $\mathrm{Mn}$ content on the Coto soil than on the Corozal soils.

Calcium content of the basal leaves was higher than that of the head

TABLE 3.-Effect of soil acidity factors on chemical composition of the basal and head leaves of cabbage growing on two Ultisols and one Oxisol

\begin{tabular}{|c|c|c|c|c|c|c|c|c|c|c|c|c|c|c|c|}
\hline \multicolumn{5}{|c|}{ Sorl acidity factors } & \multicolumn{6}{|c|}{ Basal leaves } & \multicolumn{5}{|c|}{ Head leaves } \\
\hline \multirow[t]{2}{*}{$\mathrm{pH}$} & Exch. Al & Al sat. & Ca sat. & $\frac{\mathrm{Al}}{\mathrm{Ca}}$ & $\mathrm{N}$ & $P$ & $\mathrm{~K}$ & $\mathrm{Ca}$ & $\mathrm{Mg}$ & $\mathrm{Mn}$ & $\mathrm{N}$ & $\mathrm{P}$ & $\mathrm{K}$ & $\mathrm{Ca}$ & $\mathrm{Mg}$ \\
\hline & $m e / 100 \mathrm{~g}$ & $\%$ & $\%$ & & $\%$ & $\%$ & $\%$ & $\%$ & $\%$ & $p / m$ & $\%$ & $\%$ & $\%$ & $\%$ & $\%$ \\
\hline \multicolumn{16}{|c|}{ Corozal clay soil } \\
\hline 6.00 & 0 & 0 & 73 & .00 & 2.09 & .31 & 3.10 & .97 & .27 & 147 & 2.02 & .30 & 2.97 & .74 & .30 \\
\hline 5.20 & 1.31 & 12 & 60 & .21 & 2.25 & .29 & 3.11 & .99 & .31 & 127 & 2.29 & .33 & 3.08 & .52 & .25 \\
\hline 4.90 & 3.35 & 26 & 49 & .44 & 2.48 & .27 & 3.60 & .79 & .26 & 115 & 2.47 & .35 & 3.78 & .49 & .30 \\
\hline 4.70 & 4.12 & 37 & 43 & .88 & 2.71 & .25 & 3.19 & .99 & .24 & 165 & 2.55 & .35 & 3.40 & .38 & .25 \\
\hline 4.40 & 6.41 & 52 & 30 & 1.75 & 2.50 & .25 & 3.11 & .83 & .28 & 173 & 2.67 & .30 & 3.19 & .39 & .31 \\
\hline 4.25 & 8.14 & 67 & 17 & 4.35 & 2.90 & .25 & 3.56 & .66 & .31 & 131 & 2.19 & .30 & 2.52 & .39 & .27 \\
\hline 4.10 & 10.44 & 80 & 9 & 8.90 & - & - & - & - & - & - & - & - & - & - & - \\
\hline \multicolumn{16}{|c|}{ Corozal clay subsoil } \\
\hline 5.55 & 0 & 0 & 64 & .00 & 2.21 & .28 & 3.16 & 1.10 & .34 & 81 & 2.46 & .33 & 3.53 & .70 & .30 \\
\hline 5.00 & 1.37 & 13 & 64 & .19 & 2.66 & .28 & 3.72 & .72 & .29 & 70 & 2.63 & .35 & 2.98 & .62 & .26 \\
\hline 4.75 & 3.09 & 27 & 49 & .56 & 3.11 & .25 & 3.71 & .84 & .31 & 80 & 2.61 & .37 & 2.63 & .48 & .30 \\
\hline 4.60 & 4.29 & 40 & 37 & 1.11 & 2.98 & .27 & 3.55 & .71 & .34 & 85 & 2.39 & .36 & 3.50 & .42 & .28 \\
\hline 4.50 & 5.35 & 54 & 23 & 2.38 & 3.35 & .33 & 3.67 & .77 & .38 & 125 & 2.48 & .30 & 3.61 & .40 & .31 \\
\hline 4.20 & 7.29 & 68 & 14 & 6.06 & - & - & - & - & - & - & - & - & - & - & - \\
\hline 3.95 & 9.02 & 79 & 14 & 7.58 & - & - & - & - & - & - & - & - & - & - & - \\
\hline \multicolumn{16}{|c|}{ Coto sandy clay } \\
\hline 5.60 & 0 & 0 & 52 & .00 & 3.05 & .24 & 3.39 & 1.94 & .61 & 240 & 2.35 & .21 & 2.99 & .73 & .36 \\
\hline 5.05 & .28 & 6 & 51 & .12 & 3.01 & .29 & 3.48 & 1.82 & .59 & 237 & 2.39 & .21 & 2.83 & .73 & .36 \\
\hline 4.90 & .76 & 16 & 45 & .37 & 3.08 & .25 & 3.00 & 1.97 & .65 & 275 & 2.44 & .19 & 2.89 & .73 & .35 \\
\hline 4.70 & 1.20 & 25 & 39 & .68 & 3.14 & .27 & 3.12 & 1.86 & .51 & 340 & 2.37 & .19 & 2.70 & .62 & .35 \\
\hline 4.55 & 1.51 & 34 & 34 & 1.00 & 3.12 & .19 & 3.69 & 1.90 & .53 & 310 & 2.55 & .22 & 3.04 & .62 & .30 \\
\hline
\end{tabular}

leaves on all soils and at all acidity levels. This is in agreement with Maynard et al. (9) who found a higher accumulation of $\mathrm{Ca}$ in the basal than in the head leaves of cabbage.

Composition of the head leaves was not affected by variations in soil acidity, except that $\mathrm{Ca}$ content decreased with increasing acidity on the Ultisols (tables 2 and 3). Phosphorus content of these leaves was lower and $\mathrm{Ca}$ content higher on the Coto soil than on the Ultisols. 


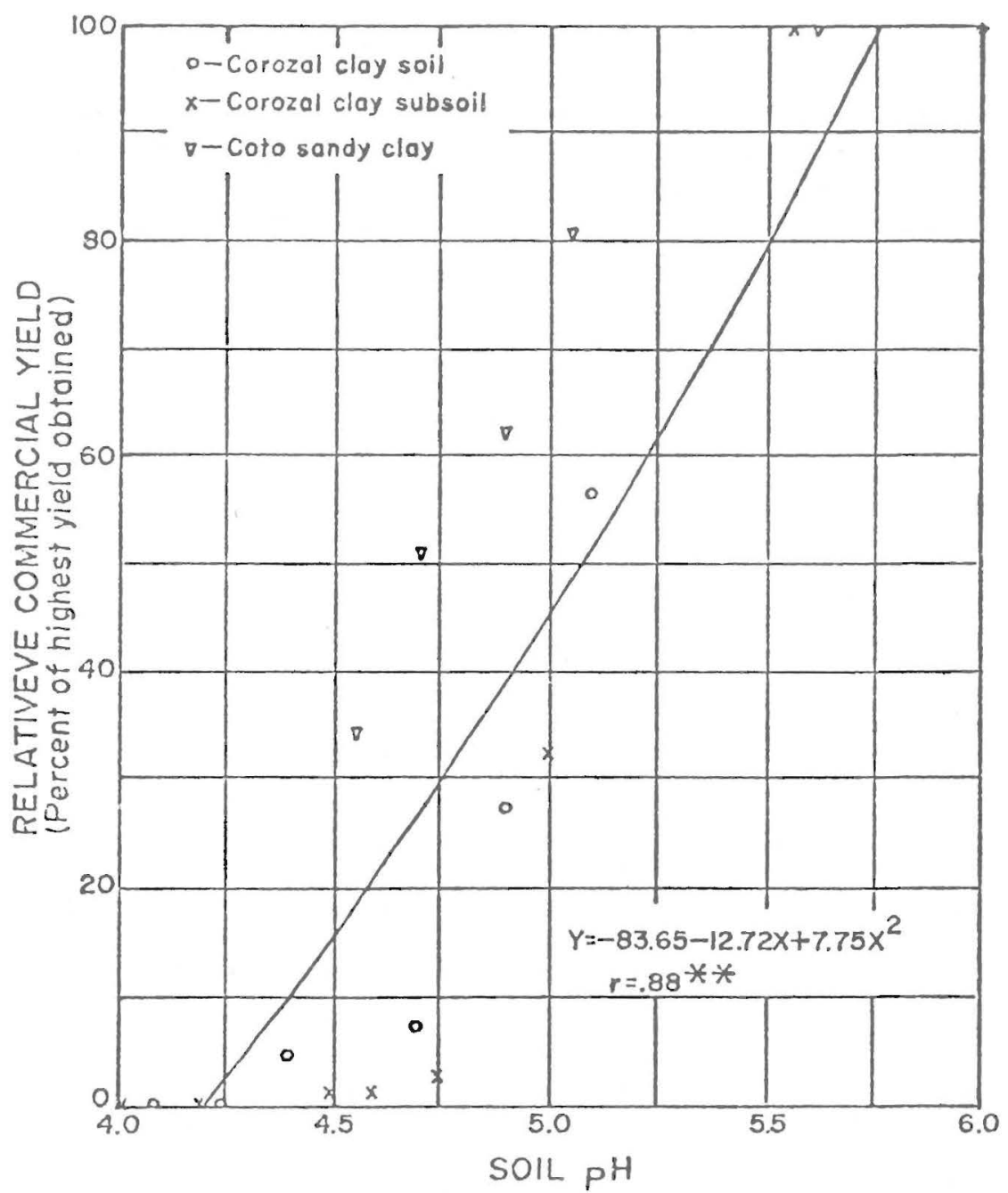

FIG. 1.-Relationship between soil $\mathrm{pH}$ and yields of cabbage on two Ultisols and one Oxisol.

Yields were significantly correlated with the various soil acidity factors (table 2), particularly with $\mathrm{pH}$ and \% Al saturation. On the Ultisols, these parameters generally explained over $80 \%$ of the variations in yields. Calcium content of the head leaves, although significantly correlated with yields on the Ultisols, explained only $34 \%$ of the variations in yields. Head density was positively correlated with soil acidity factors and negatively with yields (table 2). 


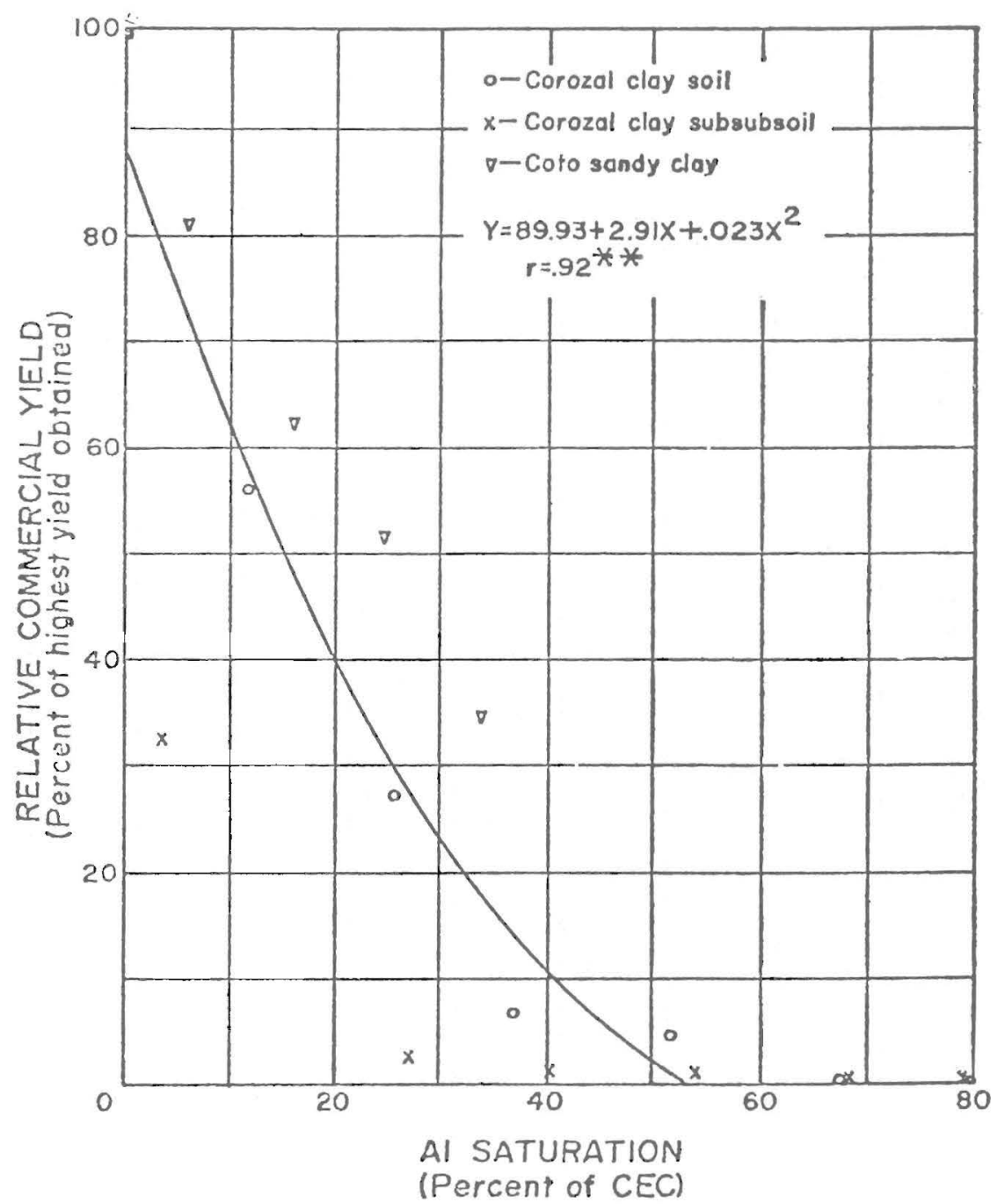

FIG. 2.-Relationship between Al saturation of the CEC of two Ultisols and one Oxisol and yields of cabbage.

Calcium content of the head leaves correlated with yields on the Ultisols but not on the Coto soil (table 2).

The combined averages for all soils show that head cabbage was very sensitive to soil acidity. Figure 1 shows that only $18 \%$ of maximum yield can be expected at $\mathrm{pH} 4.5$, a level common in Ultisols and Oxisols, only $46 \%$ at $\mathrm{pH} 5.0$, and $65 \%$, at $\mathrm{pH} 5.3$. 


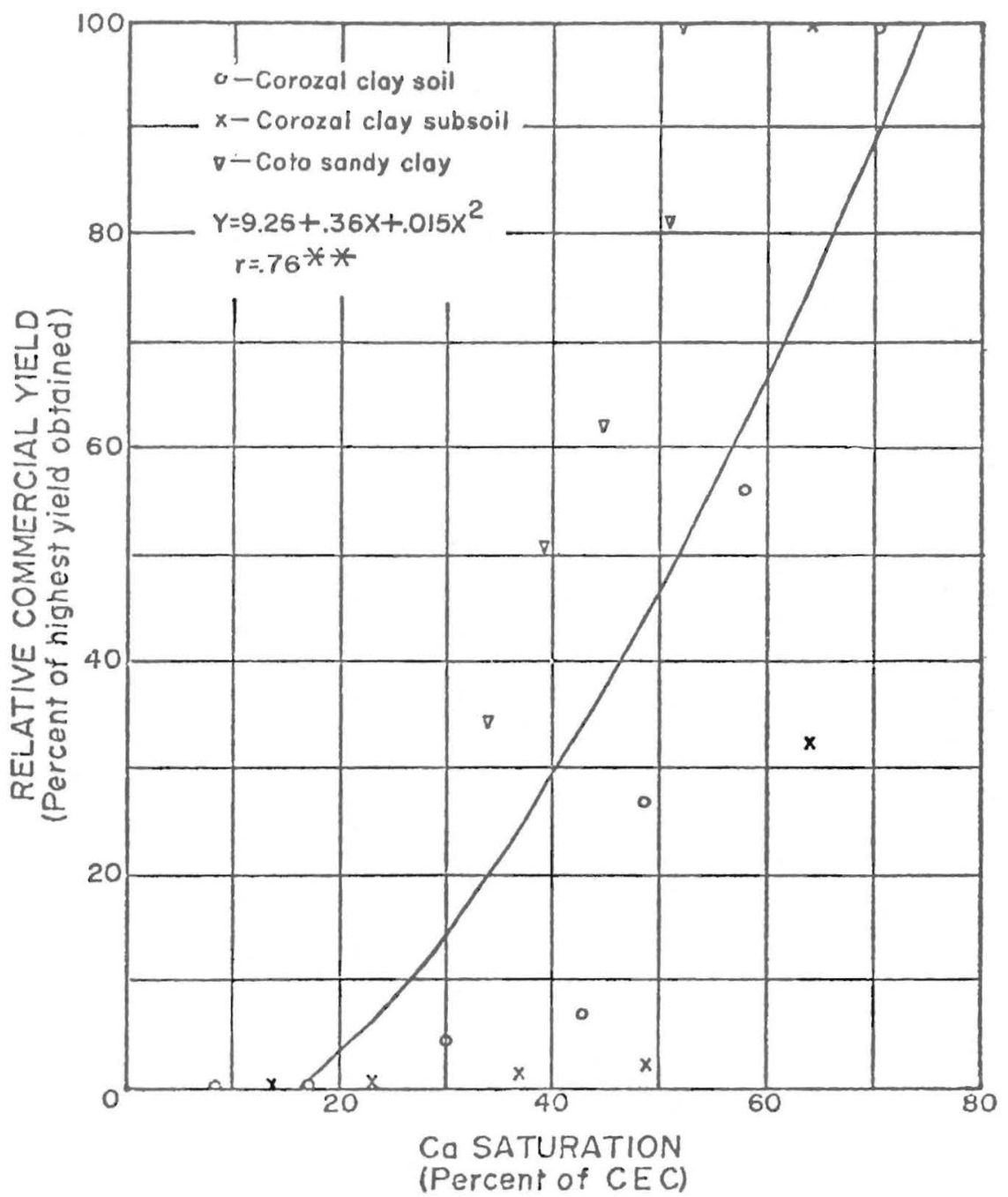

FIG. 3.-Relationship between Ca saturation of the CEC of two Ultisols and one Oxisol and yields of cabbage.

Figure 2 illustrates the sensitivity of cabbage to exchangeable Al with about $88 \%$ of maximum yields expected when there is no exchangeable $\mathrm{Al}$ in the soil and only $10 \%$ at $40 \% \mathrm{Al}$ saturation, a level very common among Ultisols and Oxisols.

Figure 3 shows that no yield can be expected below about $20 \% \mathrm{Ca}$ saturation of the exchange capacity. Walker et al. (14) have shown that sunflower and tomatoes were unable to grow when $\mathrm{Ca}$ was below $20 \%$ of 
the soil's exchange capacity, whereas sunflower was able to absorb $\mathrm{Ca}$ when it constituted only $5 \%$ of the exchange capacity of the soil.

\section{RESUMEN}

Se estudió, mediante experimentos de campo, el efecto de los factores de acidez de dos Ultisols y un Oxisol sobre la producción y composición foliar del repollo híbrido Market Prize.

Los resultados mostraron una señalada sensitividad de esta cosecha a los efectos nocivos de la acidez del suelo. En todos los casos el repollo respondió significativamente al encalado; sin embargo, la respuesta fue más favorable en los Ultisols que en el Oxisol. La producción en los Ultisols aumentó sostenidamente a medida que la saturación del suelo con aluminio intercambiable disminuyó, lográndose la máxima producción alrededor de pH 5.6. Sólo se logró un $50 \%$ de la máxima producción obtenible cuando la saturación del suelo con aluminio fue sólo de alrededor de 13\%. Apenas se logró producir rendimiento alguno cuando la saturación del suelo con aluminio alcanzó el nivel de $50 \%$, condición muy común en los Ultisols donde se cultiva repollo en Puerto Rico.

Lá densidad de los repollos se correlacionó con los factores de acidez, siendo los repollos más densos a medida que los factores de acidez aumentaron.

Los factores de acidez no mostraron efecto aparente en la composición química de las hojas exteriores, pero el contenido en calcio de las hojas que forman el repollo se correlacionó significativamente con los factores de acidez. Las hojas exteriores mostraron un contenido mayor en calcio que las hojas que forman el repollo.

\section{LITERATURE CITED}

1. Abruña-Rodríguez, F., R. W. Pearson and R. Pérez-Escolar, 1975. Lime response of corn and beans in typical Ultisols and Oxisols of Puerto Rico. Soil management in Tropical America. Univ. Consortium on Soils of the Tropics. North Carolina State Univ., Raleigh.

2. Abruña-Rodriguez, F., J. Vicente-Chandler, J. Rodriguez, J. Badillo and R. Silva, 1979. Crop response to soil acidity factors in Ultisols and Oxisols in Puerto Rico. V Sweetpotato. J. Agric. Univ. P.R. 63 (3) 250-67.

3. Anonymous, 1984. Estadisticas Agricolas de Puerto Rico 1982-83. Departamento de Agricultura, EEA de Puerto Rico.

4. Cheng, K. L. and R. H. Bray, 1951. Determination of calcium and magnesium in soil and plant material, Soil Sci. 72: 449-58.

5. Green, R. E., 1965. Head cabbage yield and leaf calcium as influenced by liming latosolic reddish prairie soil, Tech. Rep. 145. Hawaii Agric. Exp. Stn. Univ. Hawaii.

6. Harward, M. E., W. A. Jackson, W. Lott and D. D. Marson, 1955. Effects of Al, Fe and Mn upon the growth and composition of lettuce. Am. Soc. Hort. Sci. Proc. 66: 26166.

7. Hewitt, E. J., 1948. The resolution of the factors of soil acidity. IV. The relative effects of aluminum and manganese toxicities of some farm and market garden crops. Long 
Ashton Res. Stn. Ann. Rep. p. 58-65.

8. Hiatt, A. J., and J. L. Ragland, 1963. Manganese toxicity of burley tobacco, Agron. J. 55: 47-9.

9. Maynard, D. N., B. Gertein and H. F. Vernell, 1965. The distribution of calcium as related to internal tipburn, variety and calcium nutrition of cabbage, Am. Soc. Hort. Sci. Proc. 86: 392-96.

10. McLean, E. O., 1965. Aluminum. In C. A. Black et al. (Ed) Methods of soil analysis, part 2. Agronomy 9: 994-96. Am. Soc. of Agron., Madison, Wis.

11. Osuna, P., 1964. El cultivo de hortalizas, Rev. Agric. P. R. 51 (2) 15-39.

12. Pearson, O. H., 1931. Methods for determining the solidity of cabbage heads, Hilgardia 5: 382-93.

13. Pearson, R. W., R. Pérez-Escolar, F. Abruña, Z. F. Lund and E. J. Brenes, 1977. Comparative response of three crop species to liming several soils of the southeastern United States and Puerto Rico, J. Agric. Univ. P.R. 61 (3) 361-82.

14. Walker, R. B., H. M. Walker and P. R. Ashworth, 1955. Calcium-magnesium nutrition with special reference to serpentine soils, Plant Physiol. 30: 214-21. 